\title{
Communication
}

\section{A Survey of Bacterial Pathogens Detected in Feces and Wool in Small Ruminants (Pilot Study)}

\author{
María Gallardo ${ }^{1,2}$, Lucía Azócar-Aedo ${ }^{3}$, Luis Arias-Darraz ${ }^{1,4}$, Giorgio Castellaro ${ }^{5}$, Miguel Salgado ${ }^{6}$, \\ Juan Cárcamo, ${ }^{1,}$, * \\ ${ }^{1}$ Faculty of Sciences, Austral University of Chile, Valdivia, Chile \\ ${ }^{2}$ Faculty of Sciences, Mayor University, Santiago, Chile \\ ${ }^{3}$ Faculty of Medicine and Science, San Sebastian University, Puerto Montt, Chile \\ ${ }^{4}$ Fondap Research Center, Incar, Valdivia, Chile \\ ${ }^{5}$ Faculty of Agriculture and Forestry, University of Chile, Santiago, Chile \\ ${ }^{6}$ Faculty of Veterinary Sciences, Austral University of Chile, Valdivia, Chile
}

Email address:

gcarcamo@uach.cl (J. Cárcamo)

${ }^{*}$ Corresponding author

\section{To cite this article:}

María Gallardo, Lucía Azócar-Aedo, Luis Arias-Darraz, Giorgio Castellaro, Miguel Salgado, Juan Cárcamo. A Survey of Bacterial Pathogens Detected in Feces and Wool in Small Ruminants (Pilot Study). Animal and Veterinary Sciences. Vol. 7, No. 4, 2019, pp. 94-98.

doi: 10.11648/j.avs.20190704.13

Received: April 15, 2019; Accepted: May 24, 2019; Published: August 5, 2019

\begin{abstract}
Sheep feces can carry a high concentration of pathogenic and non-pathogenic bacteria, which potentially may contaminate wool as well as the shearers or wool manipulators through direct contact. A pilot study was carried out to determine the presence of bacterial DNA in feces and the degree of bacterial contamination in wool in two species of ruminants. Fourteen 2-month old lambs and 14 kids ( 7 male and 7 female), uncastrated, no twins, with their mothers, were randomly selected at weaning from a free flock grazing on naturalized pasture of Los Ríos region, Chile. Fecal and wool samples were taken once and analyzed for genomic DNA of Salmonella typhimurium containing the virulence plasmid spv, Eschrichia coli serotype O157, Clostridium perfringens type C containing $\alpha$ toxin and Mycobacterium avium sp paratuberculosis containing the IS900 insertion element. The results showed that lamb and kids feces had higher contents of bacterial DNA for E. coli O157 and SalmT than lamb wool, although only one lamb showed these two bacteria on its wool. The bacterial species influenced the DNA expression for $16 \mathrm{~S}$ in both, feces $(\mathrm{P}=0.05)$ and wool $(\mathrm{P}=0.0006)$ and for E. coli $\mathrm{O} 157$ and SalmT only in feces $(\mathrm{P}<0.0001)$. The sex was associated with $E$. coli detection in lambs feces $(\mathrm{P}<0.0007)$ and in kids feces $(\mathrm{P}<0.05)$. The values obtained for MAP IS900 and Cpa DNA contents, considering both species and sex, were undetectable. In conclusion, lamb and kids feces should potentially contaminate wool especially by Eschrichia coli $\mathrm{O} 157$ and Salmonella typhimurium, representing a potential health risk and public health concern, especially for shearers and wool handlers.
\end{abstract}

Keywords: Genomic DNA, Bacteria, Lambs, Kids

\section{Introduction}

Ovine feces are known to carry a large range of microbial indicators and pathogens (Moriarty et al. 2011 ${ }^{\mathrm{b}}$ ), which can survive for a long time on pasture [1], slurry and soil [2-4]. Cattle are considered as an important reservoir of $E$. coli serotype O157:H7 (E. coli O157) for humans, however, small ruminants may also shed bacterial pathogens to humans [5-7]. Examples the latter are: E. coli O157 [7, 8], Clostridium difficile [9], Campylobacter sp [7, 10], Salmonella sp [7], Brucella mellitensis or Coxiella burnetti [11]. Sheep and goats can also serve as reservoirs for numerous gastrointestinal pathogens [12-14], of Mycobacterium avium subsp. paratuberculosis (MAP), a pathogen that infects and affects 
primarily domestic ruminants, being sheep less susceptible to infection than goats [15] and young individuals more susceptible than old animals [16]. The presence of all the above mentioned pathogens in ruminants, in terms of risk for the public health, is not only associated to animal consumption, but also to manipulation of pathogen's contaminated animal products, such as wool, both, before and after washing [8].

The aim of the present study was to determine the presence of E. coli O157, Salmonella enterica subgroup enterica serotype typhimurium (SalmT), Clostridium perfringens Type $\mathrm{C}(\mathrm{Cpa})$ and MAP in feces and wool at the weaning period among grazing lambs and kids at weaning in grazing lambs and kids and its association with animal sex, considering the different management and normal behavior that they have, as a possible public health problem.

\section{Materials and Methods}

\subsection{Ethics}

All experimental animal procedures followed the principles of the Guide for Care and Use of Laboratory Animals and were approved by the Animal Experimental Ethical Committee of Guangdong Institute of Applied Biological Resources.

\subsection{Animal Samples}

The sampling was carried out in a farm located to $7 \mathrm{~km}$ far from Paillaco city, Los Ríos region, Chile $\left(40.1^{\circ} \mathrm{S}\right.$ and $\left.72.8^{\circ} \mathrm{W}\right)$, during December 2015. Fourteen 2-month old lambs and kids (seven un-castrated male and seven female) no twin and their mothers, were randomly selected from a large free-flock (vaccinated against clostridial diseases oncea year, plus antiparasitics twice a year), grazing on naturalized pasture until weaning, moment in which the pasture composition was measured (32\% DM, 6.18\% CP, 1.19\% EE, $0.75 \mathrm{Mcal} \mathrm{kg}^{-1} \mathrm{ME}$, $25.79 \%$ NDF, $14.49 \%$ ADF). The day before weaning, samples of feces were taken directly from the rectus. Wool was taken at the loin height. Samples were kept in Eppendorf tubes and transported on ice to the Institute of Biochemistry and Microbiology, belonging to the Universidad Austral de Chile to their storage at $-80^{\circ} \mathrm{C}$ until further analysis. Fecal (approximately $0.5 \mathrm{~g}$ ) and wool (approximately 8 fibers of the same longitude/animal) samples were taken and submitted to a DNA extraction protocol, using $300 \mu \mathrm{L}$ Chelex-100 5\%, adding $2 \mu \mathrm{L}$ lysozyme $(10 \mathrm{mg} / \mathrm{mL})$ for feces, and $2 \mu \mathrm{L}$ proteinase $\mathrm{K}$ for wool samples. The extracted DNA was kept at $-80^{\circ} \mathrm{C}$ until its analysis. The bacterial culture for each of the four bacteria considered in this study was provided by the Institute of Biochemistry and Microbiology to be used as positive controls. DNA extraction from bacterial culture was obtained using E. Z. N. A and the tissue DNA kit D3396-02, OMEGA-BIOTEK, except in the case of MAP which was extracted according to the protocol described by Salgado et al (2014).

\subsection{Genomic DNA}

The following complete coding sequences were obtained from different sources: 16S bacterial ribosomal subunit DNA [17], E. Coli O157 [18, 19], Cpa [20] and MAP IS900 [21]. For SalmT, the coding sequence was retrieved from the GenBank database (GenBank accession number 383494824). The primer design (Table 1) was developed using AmplifX 1.5 software for SalmT, E. coli, Cpa, and MAP IS900 DNA. The reaction was performed in a StepOnePlus Real-Time PCR System using 5 $\mu \mathrm{L}$ Green Master Mix Promega, with $1 \mu \mathrm{L}$ of sample as template, and $0.5 \mu \mathrm{L}$ of each primer $(10 \mu \mathrm{M})$, following a standard protocol with an initial denaturation to $95^{\circ} \mathrm{C}$ for 10 min and then 40 cycles to $60^{\circ} \mathrm{C}$. The obtained $\mathrm{Ct}$ values were used to obtain the concentration from a calibration curve prepared with different amounts of DNA from positive controls. The initial DNA concentrations to positive controls of $E$. coli O157, SalmT, MAP IS900 and Cpa, measured by spectrophotometry were $16.23,73.00,57.00$ and $48.00 \mathrm{ng} / \mu \mathrm{L}$, respectively. Each DNA control was serially diluted 7 times in proportions 1:5. The slopes from efficiency curves for dilutions of each bacterium DNA (E. coli O157, SalmT, MAP IS900 and Cpa) with its respective primers were $-3.428\left(\mathrm{r}^{2}: 0.99\right),-3.581$ $\left(r^{2}: 0.99\right),-3.531\left(r^{2}: 0.99\right)$ and $-3.718\left(r^{2}: 1.00\right)$, respectively. Arbitrary, $\mathrm{Ct}$ values $>35$ were considered negative. In order to detect pathogens in fecal and wool of small ruminants, descriptive and quantitative statistics were used. $\mathrm{LSM} \pm \mathrm{SEM}$ were estimated using GraphPad Prism statistical software version 5.03. T-test was performed to assess significant differences between means at P-value $\leq 0.05$.

Table 1. Primer specifications.

\begin{tabular}{|c|c|c|c|c|}
\hline Gene & Sequence $\left(5^{\prime}\right.$ to 3 ') & Length & Temp & Effi \\
\hline $16 \mathrm{~S}-\mathrm{F}$ & ACTCCTACGGGAGGCAGCAGT & $180 \mathrm{bp}$ & $60^{\circ}$ & $100.72 \%$ \\
\hline $16 \mathrm{~S}-\mathrm{R}$ & TATTACCGCGGCTGCTGGC & & & \\
\hline SalmT-F & AGTACGGCCGCAAGGTTAAA & $150 \mathrm{bp}$ & $65^{\circ}$ & $90.21 \%$ \\
\hline SalmT -R & AGTTCCCGAAGGCACAAATC & & & \\
\hline E. coli $\mathrm{O} 157-\mathrm{F}$ & GTACAAGTCCACAAGGAAAG & $125 \mathrm{bp}$ & $61^{\circ}$ & $95.75 \%$ \\
\hline E. coli $\mathrm{O} 157-\mathrm{R}$ & CTTGTTTCGATGAGTTTATCTGCA & & & \\
\hline Cpa-F & GCTAATGTTACTGCCGTTGA & $109 \mathrm{bp}$ & $63^{\circ}$ & $85.75 \%$ \\
\hline Cpa-R & CCTCATTAGTTTTGCAACC & & & \\
\hline MAP IS900-F & CCGCTAATTGAGAGATGCGATT & $115 \mathrm{bp}$ & $64^{\circ}$ & $91.96 \%$ \\
\hline MAP IS900-R & CCAGACAGGTTGTGCCACAA & & & \\
\hline
\end{tabular}

16S: 16s ribosomal subunit 16S; Salm: Salmonella Typhimurium (containing the virulence plasmid-spv); E. coli O157: Escherichia coli serotype O157; CPA Clostridium perfringens type C containing toxin $\alpha$; MAP IS900: Mycobacterium avium sp para-Tbc containing its insertion element IS900. 


\section{Results and Discussion}

The risk for people to become infected by zoonotic agents from small ruminants varies depending on the infectious agent, as well as the way humans handle the animals [11]. Ruminant feces can carry high concentration of pathogenic and non-pathogenic gastrointestinal bacteria [12-14], constituting a risk factor not only associated to consumption, but mainly associated to the handling of pre and post washed wool. This affects not only the wool itself, but also the shearers and wool handlers through direct contact.

Table 2 shows the bacterial DNA quantification detected in feces and wool from kids and lambs according to sex. As expected, feces showed higher content of $16 \mathrm{~S}$ bacterial DNA, E. coli O157 and SalmT than wool. Instead of the higher presence of E. coli $\mathrm{O} 157$ in feces from female lambs and kids, these bacteria were only detected in one female lamb in the same amount than in feces. SalmT was detected in 4 lambs and 3 kids feces (independent to sex). In wool, this bacteria was found only in one female lamb, the same female that tested positive to E. coli $\mathrm{O} 157$ in wool. This diagnosis can be explained by the grooming behavior among them, because this animal did not show SalmT in feces. Regarding MAP presence and Cpa, they were not detected in feces or wool.

Table 2. Individual data of total bacterial genomic DNA $(\mathrm{ng} / \mu \mathrm{L})$ in feces and wool of lambs and kids according to sex (Descriptive data).

\begin{tabular}{|c|c|c|c|c|c|c|c|c|c|c|}
\hline \multicolumn{6}{|l|}{ Lamb Feces } & \multicolumn{5}{|c|}{ Lamb Wool } \\
\hline Lambs & $16 \mathrm{~S}$ & E. coli & Salm & MAP & Cpa & $16 \mathrm{~s}$ & E. coli & Salm & MAP & $\mathrm{Cpa}$ \\
\hline Female $(n=7)$ & 0.753 & 0.013 & 0.000 & & & 0.020 & 0.000 & 0.000 & & \\
\hline Male $(n=7)$ & 1.288 & 0.090 & 0.001 & & & 0.021 & 0.000 & 0.000 & & \\
\hline Kid Feces & & & & & & Kid Y & & & & \\
\hline Kids & $16 \mathrm{~S}$ & E. coli & Salm & MAP & Cpa & $16 \mathrm{~s}$ & E. coli & Salm & MAP & $\mathrm{Cpa}$ \\
\hline Female $(n=7)$ & 1.601 & 0.009 & 0.000 & & & 0.006 & 0.000 & 0.000 & & 0 \\
\hline Male $(n=7)$ & 1.961 & 0.004 & 0.000 & & & 0.002 & 0.000 & 0.000 & & \\
\hline
\end{tabular}

DNA concentrations to calibration curves for $16 \mathrm{~S}$, E. coli $\mathrm{O} 157$, SalmT, MAP IS 900 and Cpa ranged between 86-0.01, 16.23-0.01, 73-0.1, 57-0.02, 48-0 ng/ $\mu \mathrm{L}$, respectively.

The quantification of total genomic DNA $(\mathrm{ng} / \mu \mathrm{L})$ detected in feces and lamb wool according to bacterial species and sex is shown in Table 3. The DNA expression for $16 \mathrm{~S}$ was lower in lamb than kids feces $(\mathrm{P}=0.05)$, however lambs showed higher genomic DNA contents for $16 \mathrm{~S}$ than kids wool $(\mathrm{P}=0.0006)$.
The DNA expression for E. coli $\mathrm{O} 157$ and SalmT were higher in lambs than kids feces $(\mathrm{P}<0.0001)$. In wool, E. coli $\mathrm{O} 157$ detection was undeterminable between species and significant for SalmT $(\mathrm{P}<0.001)$.

Table 3. Quantification of total bacterial genomic DNA ( $\mathrm{g} / \mu$ ) detected in feces and wool in lambs and kids according to sex (LSM $\pm S E M)$.

\begin{tabular}{|c|c|c|c|c|c|c|}
\hline Bacterial DNA (ng/ul) & Lamb feces & Lamb wool & D & Kids feces & Kids wool & D \\
\hline Between bacterial species* & $(n=7)$ & $(n=7)$ & $\mathbf{P}$ & $(n=7)$ & $(n=7)$ & $\mathbf{F}$ \\
\hline $16 \mathrm{~S}$ & $1.02 \pm 0.15$ & $0.02 \pm 0.00$ & $<0.0001$ & $1.78 \pm 0.26$ & $0.00 \pm 0.00$ & $<0.0001$ \\
\hline E. coli & $0.04 \pm 0.02$ & $0.00 \pm 0.00$ & $<0.0001$ & $0.01 \pm 0.00$ & $0.00 \pm 0.00$ & ud \\
\hline SalmT & $\begin{array}{l}0.03 \pm 0.00 \\
\text { Male Lambs }\end{array}$ & $0.00 \pm 0.00$ & $<0.0001$ & $\begin{array}{l}0.00 \pm 0.00 \\
\text { Female Lambs }\end{array}$ & $0.00 \pm 0.00$ & $<0.0001$ \\
\hline Lambs between sex** & Feces $(n=7)$ & Wool $(n=7)$ & $\mathrm{P}$ & Feces $(n=7)$ & Wool $(n=7)$ & $P$ \\
\hline $16 \mathrm{~S}$ & $0.75 \pm 0.16$ & $0.02 \pm 0.00$ & $<0.0001$ & $1.29 \pm 0.21$ & $0.02 \pm 0.00$ & $<0.0001$ \\
\hline SalmT & $\begin{array}{l}0.02 \pm 0.01 \\
\text { Male Kids }\end{array}$ & $0.00 \pm 0.12$ & $=0.0002$ & $\begin{array}{l}0.00 \pm 0.00 \\
\text { Female Kids }\end{array}$ & $0.00 \pm 0.00$ & $<0.0001$ \\
\hline Kids between sex $* * *$ & Feces $(n=7)$ & Wool $(n=7)$ & $\mathrm{P}$ & Feces $(n=7)$ & Wool $(n=7)$ & $P$ \\
\hline $16 \mathrm{~S}$ & $1.60 \pm 0.30$ & $0.01 \pm 0.00$ & $<0.0001$ & $1.96 \pm 0.44$ & $0.00 \pm 0.00$ & $<0.0001$ \\
\hline E. coli & $0.01 \pm 0.00$ & $0.00 \pm 0.00$ & ud & $0.01 \pm 0.00$ & $0.00 \pm 0.00$ & ud \\
\hline SalmT & $0.03 \pm 0.01$ & $0.01 \pm 0.00$ & $<0.001$ & $0.00 \pm 0.00$ & $0.00 \pm 0.00$ & ns \\
\hline
\end{tabular}

*For 16s: $\mathrm{P}$ value between spp (Feces) $(\mathrm{P}=0.05)$; $\mathrm{P}$ value between spp (wool) $(\mathrm{P}=0.0006)$; For $E$. coli: $\mathrm{P}$ value between spp $($ Feces $)(\mathrm{P}<0.0001)$; $\mathrm{P}$ value between spp (wool) ( $\mathrm{P}=$ ud); For Salm3: $\mathrm{P}$ value between spp (Feces) $(\mathrm{P}<0.0001)$; $\mathrm{P}$ value between $\operatorname{spp}($ wool) $(\mathrm{P}<0.001)$

**For 16s: P value between spp (male vs. female Feces) $(\mathrm{P}=\mathrm{ns})$; P value between spp (male vs. female wool) $(\mathrm{P}=\mathrm{ns})$; For $E$. coli: $\mathrm{P}$ value between spp (male vs. female Feces) $(\mathrm{P}<0.0007)$; P value between spp (male vs. female wool) ( $\mathrm{P}=\mathrm{ud}$ ); For Salm3: $\mathrm{P}$ value between spp (male vs. female Feces) ( $\mathrm{P}=\mathrm{ns})$; $\mathrm{P}$ value between spp (male vs. female wool) $(\mathrm{P}=\mathrm{ns})$

***For 16s: $\mathrm{P}$ value between spp (male vs. female Feces) $(\mathrm{P}=\mathrm{ns})$; $\mathrm{P}$ value between spp (male vs. female wool) ( $\mathrm{P}=\mathrm{ns})$; For coli: $\mathrm{P}$ value between spp (male vs. female Feces) $(\mathrm{P}=\mathrm{ns})$; $\mathrm{P}$ value between spp (male vs. female wool) $(\mathrm{P}=\mathrm{ud})$; For Salm3: $\mathrm{P}$ value between spp (male vs. female Feces) $(\mathrm{P}<0.05)$; $\mathrm{P}$ value between spp (male vs. female wool) $(\mathrm{P}=\mathrm{ns})$.

In this study, the main bacterial DNA found in feces and wool in kids and lambs was E. coli $\mathrm{O} 157$ and secondary, SalmT. Considering that the quantification of total bacterial genomic DNA $(\mathrm{ng} / \mu \mathrm{L})$ detected in pastures was $0.01 \pm 0.04$ for $16 \mathrm{~S}$, and $0.00 \pm 0.00$ for all bacteria considered in this study, it may be inferred that bacteria did not come from pastures, therefore, those bacteria came from the animal's gut. $E$. coli can be used as an indicator of water fecal 
contamination, however water also can be a source of Salmonella [22]. However, the way carcass are contaminated is not clear [23]. Certainly, the prevalence of E. coli 0157 can be reduced by avoiding the fecal contamination. An adult sheep can show E. coli concentrations of $1.62 \times 10^{7}$ per $g$ of fresh feces, being higher in spring/summer than in winter [1, 24]. Munsi et al. [25] identified that the bacterial species in feces from 20 diarrheic sheep had the ratio $30 \%$ to E. coli and $60 \%$ to Proteus mirabilis.

In the present study, E. coli $\mathrm{O} 157$ was detected only in lamb and kids feces. Mersha et al. [8] studied feces, skin and carcasses samples collected from sheep and goats from an export abattoir, detecting E. coli $\mathrm{O} 157: \mathrm{H} 7$ in most of them, with no significant differences before and after washing. Reid et al. [26] reported that the main source of carcass contamination was the skin, which can contaminate wool. Petkovsek et al. [27] found that E. coli isolates from the skin and soft tissues infection showed a high potential virulence similar to E. coli isolates described in urinary infections and bacteremia. In humans, this bacteria has been found as causative agent of neonatal omphalitis [28], necrotizing fasciitis [29] and also infections after burning [30]. Therefore, feces from lamb and kids can potentially contaminate wool, especially with $E$. coli and SalmT, representing an important zoonotic risk for shearers and wool handlers.

Regarding Cpa, the differences between feces and wool found within species or between species were undeterminable, being consistent with the results reported by Gkiourtzidis et al. [31], showing Cpa (which contains the $\alpha$-toxin) was not found in feces. Regarding MAP IS900, the differences between feces and wool found within species were non significant and undeterminable, respectively.

In the present study no significant differences between sex for 16S DNA expression in feces or wool were found $(\mathrm{P}>0.05)$. In feces, E. coli $\mathrm{O} 157$ detection was higher in female than male lambs $(\mathrm{P}<0.0007)$, without any significant difference between female and male kids $(\mathrm{P}>0.05)$. The SalmT detection was higher in male than female kids $(\mathrm{P}<0.05)$ but not between male and female lambs $(\mathrm{P}>0.05)$. In wool the DNA expression for $E$. coli $\mathrm{O} 157$ was undeterminable between sex in lambs, which was not significant between sex in kids. SalmT detection was not significant between in sex. Instead, there are no publications related to bacterial pathogens and sex, Cong et al. [32] found a change in the bacterial composition according to sex (more amount of Clostridiates, and less of Enterobacteria in female than male in the gastrointestinal tract during early age and breastmilk feeding type (kids fed mother's own breastmilk showed a higher abundance in Clostridiates and Lactobacillus than those fed non mother's own breastmilk).

\section{Conclusion}

In the present study we found the lamb and kids feces had higher contents of bacterial DNA for E. coli 0157 and SalmT than lamb wool, although only one lamb showed these two bacteria on its wool. The bacterial species influenced the DNA expression for $16 \mathrm{~S}$ in both, feces $(\mathrm{P}=0.05)$ and wool
$(\mathrm{P}=0.0006)$ and for E. coli $\mathrm{O} 157$ and SalmT only in feces $(\mathrm{P}<0.0001)$. The sex was associated with $E$. coli detection in lambs feces $(\mathrm{P}<0.0007)$ and in kids feces $(\mathrm{P}<0.05)$. The values obtained for MAP IS 900 and Cpa DNA contents, considering both species and sex, were undetectable. It was concluded that lamb and kids feces could potentially contaminate wool with E. coli (particularly in female lambs) and SalmT (especially in male lambs and kids), representing an important health risk for shearers and wool handlers, which must be considered as a public health concern. Further studies should be focused on finding effective measures to address different levels of infection in alive animals to control the direct skin contamination (because prevention is not possible due to the normal animal behavior) as a way to minimize the human zoonotic infection risk.

\section{Conflict of Interest}

The authors declare that they have no competing interests.

\section{Acknowledgements}

We would like to thank to FONDECYT grants 3160059 , 1150934 and FONDAP 15110027 for financing this study.

\section{References}

[1] Moriarty, E. M., Mackenzie, M. L., Karki, N., Sinton,. LW, 2011ª Survival of indicator and pathogenic bacteriain sheep feces on pasture. Applied and Environmental Microbiology, 75: 6.

[2] Kudva, I. T., Blanch, K., Hovde, C. J. 1998. Analysis of Escherichia coli $\mathrm{O} 157: \mathrm{H} 7$ survival in ovine or bovine manure and manure slurry. Applied and Environmental Microbiology, 64: 3166-3174.

[3] Avery, L. M., Killham, K., Jones, D. L. 2005. Survival of $E$. coli $\mathrm{O} 157: \mathrm{H} 7$ in organic wastes destined for land application. Journal of Applied Microbiology, 98: 814-822.

[4] Williams, A. P., Gordon, H., Jones, D. L., Strachan, N. J. C., Avery, L. M., et al. 2008. Leaching of bioluminescent Escherichia coli $\mathrm{O} 157: \mathrm{H} 7$ from sheep and cattle faeces during simulated rainstorm events. Journal of Applied Microbiology, 105: 1452-1460.

[5] Blanco, M., Blanco, J., Mora, A., González, E., Bernárdez, M., et al. 2003. Verotoxin-producing Escherichia coli (VTEC) in Spain: prevalence, serotypes, and virulence genes of O157:H7 and non- O157 VTEC in ruminants, raw beef products and humans. Experimental Biology and Medicine, 228: 345-351.

[6] Battisti, A., Lovari, S., Franco, A., Diegidio, A., Tozzoli, R., et al. 2006. Prevalence of Escherichia coli O157 in lambs at slaughter in Rome, central Italy. Epidemiology and Infection, 134: 415-419.

[7] Hanlon, K., Miller, M., Guillen, M., Echeverry, A., Dormedy, E., et al. 2018. Presence of Salmonella and Escherichia coli O157 on the hide, and presence of Salmonella, Escherichia coli O157 and Campylobacter in feces from small ruminant (goat and lamb) samples collected in the United States, Bahamas and Mexico. Meat Science, 138: 1-5. 
[8] Mersha, G., Asrat, D., Zewde, B. M, Kyule, M. 2010. Occurrence of Escherichia coli O157:H7 in faeces, skin and carcasses from sheep and goats in Ethiopia. Letters in Applied Microbiology, 50: 71-76.

[9] Knight, D. and Riley, T. 2013. Prevalence of gastrointestinal Clostridium difficile carriage in Australian sheep and lambs. Applied and Environmental Microbiology, 79 (18): 5689-92.

[10] Schilling, A. K., Hotzel, H., Methner, U., Sprague, L., Schmoock, G., et al. 2012. Zoonotic agents in small ruminants kept on city farms in Southern Germany. Applied and Environmental Microbiology, 78 (11): 3785-93.

[11] Ganter, M. 2015. Zoonotic risks from small ruminants. Veterinary Microbiology, 181: 53-65.

[12] Hancock, D., Besser, T., Lejeunes, J., Davis, M., Rice, D. 2001. The control of VTEC in the animal reservoir. International Journal of Food Microbiology, 66: 71-78.

[13] Brown, P. E., Christensen, O. F., Clough, H. E., Diggle, P. J., Hart, C. A., et al. 2004. Frequency and spatial distribution of environmental Campylobacter spp. Applied and Environmental Microbiology 70: 6501-6511.

[14] Cox, P., Griffith, M., Angles, M., Deere, D., Ferguson, C. 2005. Concentrations of pathogens and indicators in animal feces in the Sydney watershed. Applied and Environmental Microbiology, 71: 5929-5934.

[15] Dimareli-Malli, Z., Stevenson, K., Sarris, K., Sossidou, K. 2009. Study of microbiological and molecular typing aspects of paratuberculosis in sheep and goats in northern Greece. Transbounary and Emerging Diseases, 56: 285-290.

[16] Delgado, L., García Marín, J. F., Muñoz, M., Benavides, J., Juste,. RA., et al. 2013. Pathological findings in young and adult sheep following experimental infection with 2 different doses of Mycobacterium avium subspecies paratuberculosis. Veterinary Pathology, 50: 857-866.

[17] Clifford, R. J., Milillo, M., Prestwood, J., Quintero, R., Zurawski, D., et al. 2012. Detection of bacterial 16S sRNA identifcation of four clinically important bacteria by real-time PCR. PLoS ONE 7 (11), e48558. doi: 10.1371/journal.pone.0048558.

[18] Guy, RA., Tremblay, D., Beausoleil, L., Harel, J., Champagne, M. 2014. Quantification of E. coli $\mathrm{O} 157$ and STEC in feces of farm animals using direct multiplex real time PCR (qPCR) and a modified most probable number assay comprised of immunomagnetic bead separation and qPCR detection. Journal of Microbiological Methods, 99: 44-53.

[19] O’Hanlon, K. A., Catarame, T. M. G., Duffy, D., Blair, I. S., McDowell, D. A. 2004. Rapid detection and quantification of $E$. coli $\mathrm{O} 157 / / \mathrm{O} 26 / \mathrm{O} 111$ in minced beef by real-time PCR. Journal of Applied Microbiology, 96: 1013-1023.
[20] Garmory, H. S., Chanter, N., French, N. P., Bueschel, D., Songer, J. G., et al. 2000. Occurrence of Clostridium perfringens beta2-toxin amongst animals, determined using genotyping and subtyping PCR assays. Epidemiology and Infection, 124: 61-67.

[21] Herthnek, D. and Bolske, G. 2006. New PCR systems to confirm real-time PCR detection of Mycobacterium avium subsp. paratuberculosis. BMC Microbiol 6, 87. http://dx.doi.org/10.1186/1471-2180-6-87.

[22] Field, K. G. and Samadpour, M. 2007. Fecal source tracking, the indicator paradigm, and managing water quality. Water Research, 41: 3517-3538.

[23] Davies, R. H., Dalziel, R., Gibbens, J. C., Wilesmith, J. W., Ryan, J. M. B., et al. 2004. National survey for Salmonella in pigs, cattle and sheep at slaughter in Great Britain (19992000). Journal of Applied Microbiology, 96: 750-760.

[24] Moriarty, E. M., McEwan, N., Mackenzie, M., Karki, N., Sinton, L. W., et al. 2011 ${ }^{\mathrm{b}}$. Incidence and prevalence of microbial indicators and pathogens in ovine faeces in New Zealand. New Zealand Journal of Agricultural Research, 54: 10.

[25] Munsi, N., Ershaduzzaman, Gani, O., Khanduker, M., Alam, S. 2015. Identification of bacterial agents from the faecal samples of diarrheic sheep and their antibiotic sensitivity. Research in Agriculture, Livestock and Fisheries, 2 (3): 453-457.

[26] Reid, C., Small, A., Avery, S., Buncic, S. 2002. Presence of food-born pathogens on cattle hides. Food Control 13 (6): 411-415.

[27] Petkovsek, Z., Elersic, K., Gubina, M., Zgur-Bertok, D., Starcic Erjavec, M. 2009. Virulence potential of Escherichia coli isolates from skin and soft tissue infections Journal of Clinical Microbiology, 47 (6): 1811-1817.

[28] Fraser, N., Davies, B. W., Cusack, J. 2006. Neonatal omphalitis: a review of its serious complications. Acta Paediatrica, 95: 519-522.

[29] Afifi, R. Y. and El-Hindawi, A. A. 2008. Acute necrotizing fasciitis in Egyptian patients: a case series. International Journal of Surgery, 6: 6-14.

[30] Rodgers, G. L., Mortensen, J., Fisher, M. C., Lo, A., Cresswell, A., et al. 2000. Predictions of infectious complications after burn injuries in children. The Pediatric Infectious Disease journal 19: 990-995.

[31] Gkiourtzidis, K., Frey, J., Bourtzi-Hatzopoulou, E., Iliadis, N., Sarris, K. 2001. PCR Detection and prevalence of alpha-, beta-, beta 2-, epsilon-, iota- and enterotoxin genes in Clostridium perfringens isolated from lambs with clostridial dysentery. Veterinary Microbiology, 82: 39-43.

[32] Cong, W., Xu, W., Janton, S., Henderson, W. A., Matson, A., et al. 2016. Gut microbiome developmental patterns in early life of preterm infants: impacts of feeding and gender. PLoS ONE 11 (4), e0152751. doi: 10.1371/journal. pone.0152751. 